\title{
Sustainability Analysis in Agricultural Policies in Benin
}

\author{
Clotilde Gnon Bio N'Goye (Corresponding Author) \\ Society and Environnement Laboratory (LaSEn), University of Parakou (UP), Benin \\ Tel: +22994694708Ｅ-mail: cbiongoye@yahoo.fr
}

Janvier Egah

Society and Environnement Laboratory (LaSEn), University of Parakou (UP), Benin

Tel: +22996371779Ｅ-mail: egahjanvier@gmail.com

Mohamed Nasser Baco

Society and Environnement Laboratory (LaSEn), University of Parakou (UP), Benin

Tel: +22996061664Ｅ-mail: nasserbaco@yahoo.fr

$\begin{array}{lrr}\text { Received: Nov. 16, } 2020 & \text { Accepted: Dec. 17, 2020 Published: Dec. 23, } 2020 \\ \text { doi:10.5296/jas.v9i1.17940 } & \text { URL: https://doi.org/10.5296/jas.v9i1.17940 }\end{array}$

\begin{abstract}
Agriculture in Benin is confronted with new problems which require more sustainable and resilient strategies for its development. The question of its sustainability is thus at the center of agricultural policies. This study analyzed how issues of sustainability of farming systems are taken into account in argicultural policies frameworks. An analysis and review of the four main agricultural policy documents adopted over the last thirty years being completed to assess the measures taken to ensure the sustainability of farms. It emerges that agricultural policies do not integrate into their framework the pillars on which the development of sustainable agriculture is based. However, in their implementation, they have been strongly oriented towards the pursuit of economic and social objectives, which is reflected in the will to improve the productivity and attractiveness of the agricultural sector. However, the lack of long-term strategies, the lack of coherence between policies and the dependence on the international political context has not allowed interventions in the agricultural sector to be placed in a sustainable perspective.
\end{abstract}


Keywords: agricultural policies, family farms, sustainable agricultural development, Benin

\section{Introduction}

In most sub-Saharan African countries, agricultural development represents the basis for economic growth and strongly influences social change (Felix, 2006; Gafsi et al., 2007). Thus, agriculture remains an important sector of activity in Benin, which still employs about $70 \%$ of the active population, contributes about 33\% of the Gross Domestic Product (GDP), provides about $75 \%$ of export earnings and $15 \%$ of state revenues (INSAE, 2015). Given this importance, the State is implementing policies to support its development and transformation to make it more sustainable. Two major ideologies have thus inspired political reforms in the agricultural sector over the last three decades: the new democracy after 1990 and political alternation from 2006 onwards (Adjovi, 2014). These ideologies have led to political choices of direction in agriculture that have shaped the development of the agricultural sector and have given it the impetus it needs today. However, despite the many potentialities recognized in the agricultural sector and the many actions implemented to ensure its development, the promotion of agriculture in Benin is far from fulfilling the hopes placed in it. Although there have been significant changes in production systems in recent years, agriculture in Benin has not significantly changed in scale (MAEP, 2017). Low agricultural productivity and damage to environmental and natural resources management are observed in the sector, raising concerns about the sustainability of farms (Amoussou et al., 2016; Assogba et al., 2017). Recent diagnostics of the agricultural sector indicate a worrying level of occupation and degradation of agricultural land, its increasing scarcity and increasing exposure of farms to the effects of climate change (Amonmide et al., 2019; Amoussou et al., 2016). Similarly, according to World Bank data (2020), over the last three decades, agricultural land use has increased twice as fast as the previous period (Banque Mondiale, 2020), resulting in high land pressure and migration of agricultural populations. These findings pose serious challenges to the sustainability of existing agricultural models, which is reflected in their capacity to ensure the reproduction of production systems and the natural resources on which they are based (Médulline Terrier et al., 2010).

In this context, the many reflections on sustainable agriculture have been more oriented towards the sustainability of organizational, technical and economic practices at the farm level than the possibility of policy choices to achieve sustainable systems. However, it is the policy orientations given to the agricultural sector that structure and determine to a large extent the behaviour of the actors involved in the sector, including that on farms. The practices observed on the farms are therefore the expression of the content of the development models defined through the policies and the measures taken for their implementation. An analysis of these policies is consequently relevant to provide answers to the conditions for achieving the sustainability of agricultural systems.

What is the vision of sustainable agriculture development held by agricultural policies? How do they take into account sustainability in the agricultural sector? This article analyzes the inclusion of sustainability in the agricultural policies of Benin. 


\section{Theoretical Framework}

\subsection{Agricultural Policies}

Agricultural policy is defined as all public interventions in the agricultural sector (Tribier, 2014). The public intervention concerns the actions carried out by the State in its centralized structures on one side, and at all levels of decentralization on the other. As well as public actions aimed at guiding and coordinating the actions of private actors. It is generally characterized by "a set of regulatory measures, structural arrangements, financial and human resources, implemented by the public authorities to contribute to the progress of the agricultural sector" (Tribier, 2014).

The policies involve : (i) strategic orientations (policy documents), programs and projects, (iii) a set of regulations (law, decree, order, etc.), (iv) commitments/declarations/promises by an actor invested with public authority.

\subsection{Sustainability Analysis Framework}

Sustainability often refers to the notion of sustainable development that first appeared in 1987 with the "Brundtland" report, which advocated a global partnership to enable the behaviour of development actors to evolve on global problems (Sirdey et al., 2012). The sustainability of a model reflects its economic, social and technical sustainability. In other words, it characterizes the state of a system and its capacity to endure over time (Lairez et al., 2015).

Much research has been conducted on the use of the concept of sustainability in general and its application to agricultural production systems (Barbier \& Lopez-Ridaura, 2010; Zahm et al., 2015, 2019). This shows that the analysis of the sustainability of a system operates at two levels: the intrinsic sustainability of the system and the contribution of the system to the sustainability of an encompassing system. In this paper, interest is given to the inherent sustainability of agricultural policies and their content that contributes to the sustainability of other agricultural systems. Three levels of analysis have been used to assess this sustainability: (i) the policy development process, (ii) the consistency of orientations in the sector, (iii) the inclusion of the conditions of agricultural systems sustainability in the content of policies.

At the farming systems level, it is well accepted that sustainability depends on four essential pillars: viability, livability, reproducibility and transmissibility (Landais, 1998). In this study, the reading grid of farm sustainability proposed by Landais (figure, 1) combined with the intrinsic analysis of agricultural policies was used to assess the involvement of agricultural policies in the sustainability of agricultural systems in Benin. 


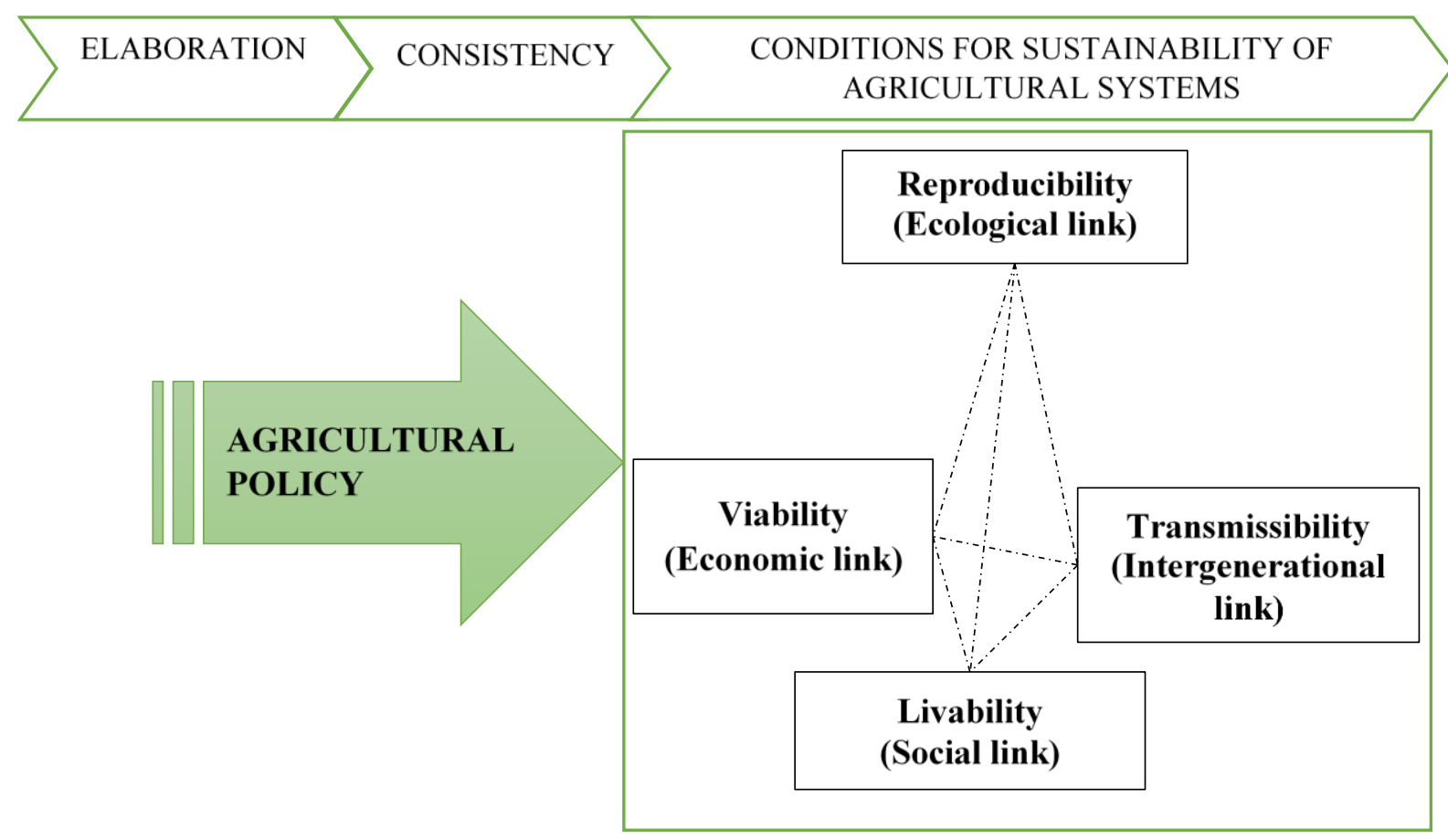

AGRICULTURAL SYSTEM

Figure 1. Agricultural policy sustainability analysis framework

Source: adapted from Landais (1998)

\subsection{Methodological Framework}

The present research was conducted in Benin by considering the agricultural sector policy documents developed over the last thirty years (Table 1). These documents have made it possible to better account for the various interventions in the sector.

The last thirty years, which began in the 1990s, correspond in Benin to the era of democratic renewal. During this period, important reforms were undertaken to provide the agricultural sector with an orientation that brings it into conformity with the requirements of the insertion of the national economy in globalization.

These strategy documents present an overall vision of the agricultural sector, broken down into strategic areas of intervention by sub-sector. The various support measures are defined according to the axes to serve as guidelines for the interventions of the various actors for the development of agriculture. 
Table 1. Strategic orientation documents used in the project

\begin{tabular}{l|l|l|l}
\hline Strategic documents & $\begin{array}{l}\text { Economic and political } \\
\text { context }\end{array}$ & Document structure & Period \\
\hline $\begin{array}{l}\text { Rural Development } \\
\text { Policy Declaration } \\
\text { Letter (LDPDR) }\end{array}$ & $\begin{array}{l}\text { - Democratic Renewal } \\
\text { - Economic neoliberalism }\end{array}$ & $\begin{array}{l}\text { Six political } \\
\text { orientations for the } \\
\text { rural sector }\end{array}$ & 1991 \\
\hline $\begin{array}{l}\text { Master plan for } \\
\text { agricultural and rural } \\
\text { development (SDDR) }\end{array}$ & $\begin{array}{l}\text { Millennium Declaration for } \\
\text { Development }\end{array}$ & $\begin{array}{l}\text { Nine main themes for } \\
\text { the development of } \\
\text { the agricultural sector }\end{array}$ & 2000 \\
\hline $\begin{array}{l}\text { Strategic Plan for the } \\
\text { revival the } \\
\text { agricultural sector } \\
\text { (PSRSA) }\end{array}$ & $\begin{array}{l}\text { - Policy of Change and } \\
\text {-Millennium Development } \\
\text { Goals (MDGs) }\end{array}$ & $\begin{array}{l}\text { Fourteen strategic } \\
\text { objectives for the } \\
\text { sustainable } \\
\text { development of the } \\
\text { agricultural sector. }\end{array}$ & 2011 \\
\hline $\begin{array}{l}\text { Strategic Plan for the } \\
\text { Development of the } \\
\begin{array}{l}\text { Agricultural Sector } \\
\text { (PSDSA) }\end{array}\end{array}$ & $\begin{array}{l}\text { - Termination and New Start } \\
\text { policy } \\
\text { - Sustainable development } \\
\text { Goals (SDGs) }\end{array}$ & $\begin{array}{l}\text { Five areas of } \\
\text { intervention for the } \\
\text { development of the } \\
\text { agricultural sector }\end{array}$ & 2017 \\
\hline
\end{tabular}

The data collected are essentially the global vision of the sector, the strategic axes, the development objectives models and the strategic priorities in each sub-sector.

The contribution of policies to the sustainability of operating systems was analyzed through the Landais grid (1998). Based on the definitions given for each of the pillars of sustainability (Briquel et al., 2001; Landais, 1998; M. Terrier et al., 2013), indicators that can be used to measure the different pillars of sustainability at the farming systems level are defined. The operational variables are selected based on the components that allow the measurement of each indicator (Table 2). The weighted scoring method used in multi-criteria assessments (Briquel et al., 2001; Zahm et al., 2019) of sustainable agriculture is used. Thus, based on the assumption that all the strategic axes have the same importance in the policies and that the pillars of sustainability have the same weight, a score of 1 point is assigned to each sustainability pillar identified through each sub-sectoral strategic axis. The score for each pillar in each orientation has been assigned in proportion to the number of identified indicators that make it up. A pillar only totals 1 point in a given axis if the set of indicators composing it is identified. On the other hand, when none of the indicators is identified, the pillar is given a score of 0 .

This approach has made it possible to define the rate at which each pillar of sustainability is taken into account in the strategic documents to know their orientation for the development of the agricultural sector. 
Table 2. Operationalization of indicators for taking into account the sustainability of agricultural systems in policies

\begin{tabular}{|c|c|c|c|}
\hline Pillars & Indicators & Operational variables & $\begin{array}{l}\text { Score by } \\
\text { indicator }\end{array}$ \\
\hline \multirow[t]{2}{*}{ Viability } & $\begin{array}{l}\text { Securing the } \\
\text { production system }\end{array}$ & $\begin{array}{l}\text { Technical and economic performances - } \\
\text { Autonomy - Diversification - Flexibility } \\
\text { and sensitivity to hazards - Integration of } \\
\text { sectors }\end{array}$ & 0,5 \\
\hline & $\begin{array}{l}\text { Securing outlets } \\
\text { and prices }\end{array}$ & Development of value chains & 0,5 \\
\hline Livability & $\begin{array}{l}\text { Quality of life for } \\
\text { the operator and } \\
\text { his family }\end{array}$ & $\begin{array}{l}\text { Ability to control the operation of the } \\
\text { system - Ability to assume the risks } \\
\text { incurred - Working conditions and } \\
\text { arduousness - Physical risks - Integration } \\
\text { into local professional networks }\end{array}$ & 1 \\
\hline \multirow{2}{*}{ Transmissibility } & $\begin{array}{l}\text { Renewal of the } \\
\text { agricultural } \\
\text { population }\end{array}$ & $\begin{array}{l}\text { Image of agricultural activity - } \\
\text { Representation in the local society of } \\
\text { agricultural trades and farmers' lifestyles }\end{array}$ & 0,5 \\
\hline & $\begin{array}{l}\text { Renewal of } \\
\text { agricultural } \\
\text { activity }\end{array}$ & $\begin{array}{l}\text { Access and resource management } \\
\text { standards and regulations }\end{array}$ & 0,5 \\
\hline \multirow{2}{*}{ Reproducibility } & $\begin{array}{l}\text { Ecological quality } \\
\text { of agricultural } \\
\text { practices }\end{array}$ & $\begin{array}{l}\text { Adaptation of production systems and } \\
\text { technical itineraries to local } \\
\text { environments }\end{array}$ & 0,5 \\
\hline & $\begin{array}{l}\text { Quality of } \\
\text { human-nature } \\
\text { relationships }\end{array}$ & $\begin{array}{l}\text { Protection of the environment and } \\
\text { biodiversity - Maintenance of space - } \\
\text { Landscape production - Land use } \\
\text { planning }\end{array}$ & 0,5 \\
\hline
\end{tabular}

Source: Adapted from Landais (1998), Terrier et al (2010) and Zahm et al (2019). 


\section{Results}

\subsection{Characterization of the Strategic Orientations for the Development of Benin's Agricultural Sector}

The strategic orientations that have marked agricultural development since 1990 have been based on the same constraints and challenges. However, the strategic objectives and development models are not the same (Figure 2).

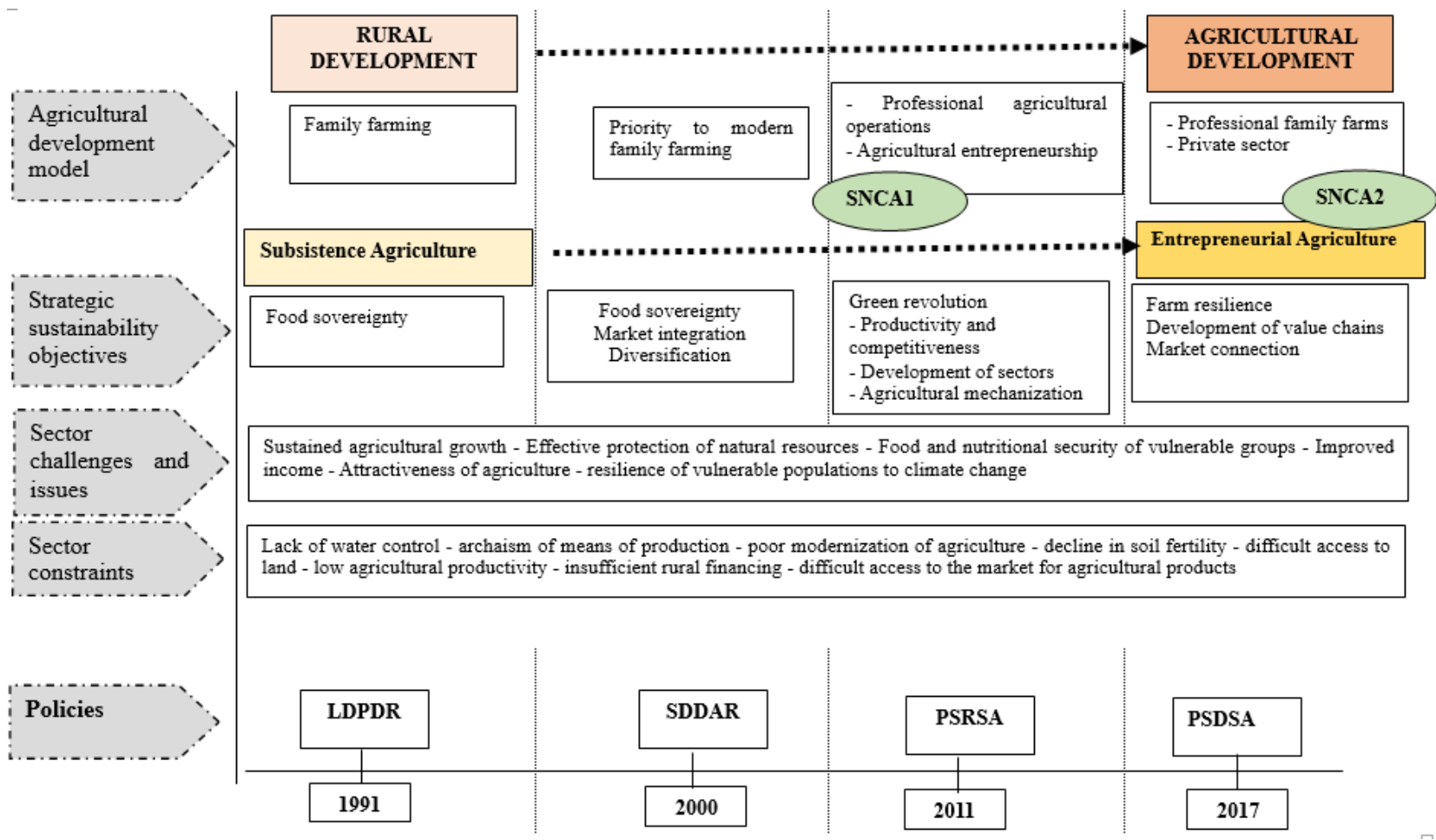

Figure 2. Synthetic model of the trajectory of the strategic orientations of the agricultural sector in Benin

The LDPDR published in 1991, updated with the Rural Development Policy Declaration (DPDR) of 1999, as well as the SDDR of 2000 have more oriented interventions in Benin's agricultural sector towards the development of family farming and its modernization. This is the consecration of a factual state of affairs in Benin's agriculture. It is in fact made up of small family farms, considered to be the basis of agricultural and economic development. The objectives have been to raise the standard of living of the population by conquering markets and improving productivity, particularly through the promotion of improved production systems adapted to the different agro-ecological conditions and technologies adapted to the environment.

With the PSRSA adopted in 2011 and the PSDSA in 2017, the emphasis has been placed on the professionalization of family farms and the development of agricultural entrepreneurship through the "Green Revolution". Family farms were to professionalize alongside agricultural enterprises for a change of scale in Benin agriculture. The accompanying measures put in place consisted of promoting access to quality inputs, agricultural equipment, agricultural 
credit and insurance, market information and specialized advice.

Over the past 30 years, the objectives of sustainability and agricultural development models have shifted from the pursuit of food sovereignty with subsistence agriculture to the development of agricultural value chains through entrepreneurial agriculture.

\subsection{Taking Sustainability into Account in Agricultural Policy Guidelines}

The vision of agricultural sustainable development is included in the main objective of agricultural policies. Although the diagnosis of the agricultural sector is not based on the pillars of sustainability, the objectives and strategic orientations (SOs) given to the sector have made it possible to identify the actions that contribute to it. The analysis of sustainability in the strategic orientations generally showed that the SOs were more focused on viability and livability. On the other hand, transmissibility and reproductibility were rarely and less taken into account (Figure 3).

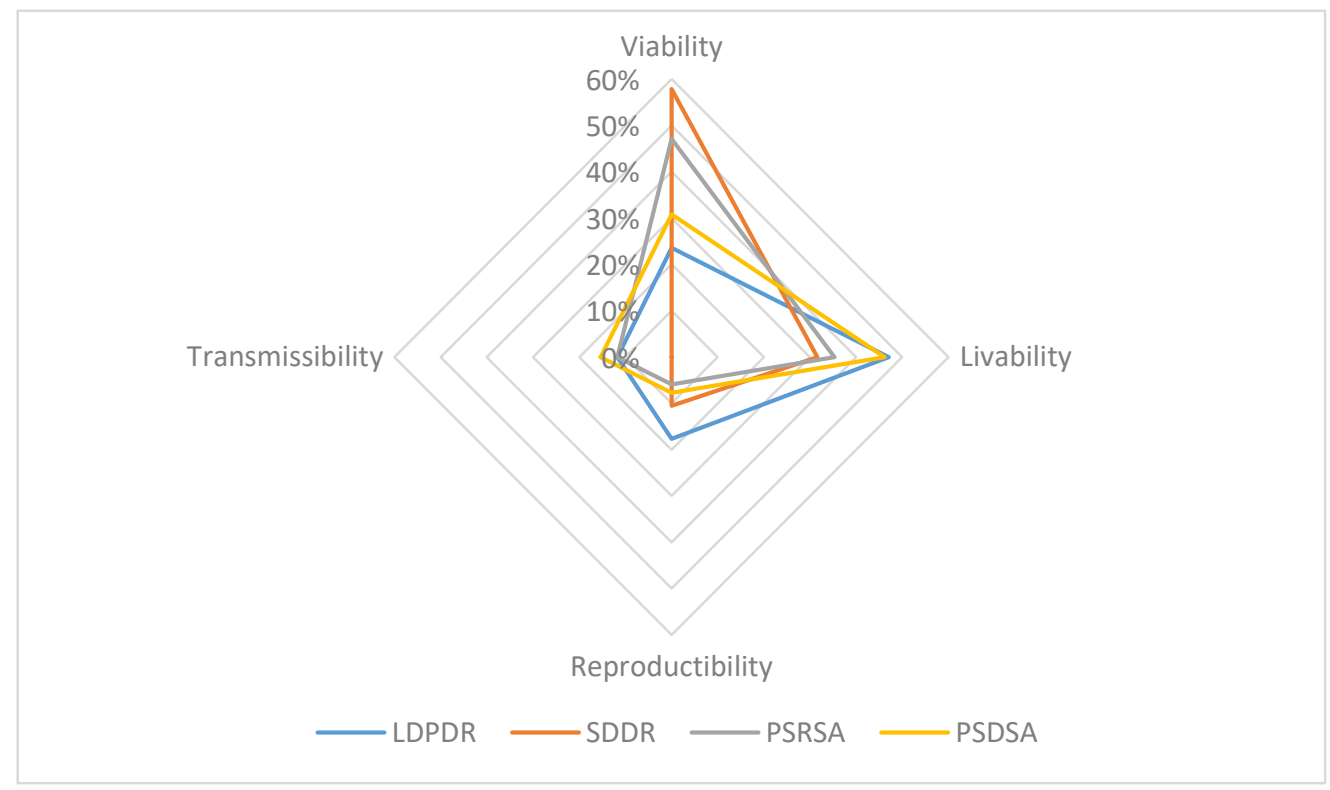

Figure 3. Orientations of agricultural policies

The LDPDR and the PSDSA are social policies for agricultural development (livability), while the SDDAR and the PSRSA are oriented towards the economic development of agriculture (viability). Thus, the LDPDR's priority was to improve the living conditions of rural populations marked by a very high level of precariousness, particularly through greater participation in trade that provides income to the farmer to help improve his standard of living and that of his family. The SDDR reinforces this policy choice by emphasizing the modernization of family farms, which should be carried out with the mechanization of agricultural activities to meet the challenges of food security in a context of the demographic explosion. In this context of economic and political change, the PSRSA intervened with the idea of a green revolution that should help improve the performance of the sector and the living and working conditions of farmers, as well as the attractiveness of the agricultural sector through the implementation of measures to promote the development of agricultural 
activities by young people. As for the PSDSA, it focuses on improving governance and the overall performance of the sector by integrating value chains and improving farm productivity.

In general, the pillars of sustainability relating to replicability and transferability have received less attention, due to the diagnosis of the sector which reveals a still low level of performance and the need to increase the overall productivity of the sector to meet the challenges ahead.

A reading of the orientations over of the policies shows an improvement in the consideration of human capital in agricultural development, particularly through the strengthening of the livability and transmissibility of agricultural activity. There is thus a decline in interest in the viability of the sector in favor of the social strengthening of agricultural activity, which is materialized by an improvement in working conditions and governance of the sector. However, despite the global awareness of environmental issues, the various policies do not insist on the issue although strategies to strengthen the resilience of farms are set out in the guidelines.

\section{Discussion}

\subsection{Agricultural Policy in Trial and Error}

Since 1990, the results of the diagnostics on which the implementation of agricultural policies is founded have not changed significantly. However, in response to this diagnosis, the orientations of the policies have brought such diverse responses. Several factors can explain these decadences; these are on the part of the influence of the international economic environment and on the others, the national political context changing and the non-existence of a vision for the long-term development of the agricultural sector.

The structural adjustment procedures in which most African states found themselves in the years following the 1990s caused them to lose control of their policies. Strategic orientation documents are drafted by cooperation agencies or by their experts (Chaboussou \& Ruello, 2006). The format of the documents thus varies according to the wishes of the sponsors (agricultural policy declaration letter, rural development plan, strategic operational plan, etc.), but they generally follow the same spirit by removing the control levers from the states (Courade \& Devèze, 2006; Mercoiret, 2006; Ribier \& Baris, 2014). This hostage-taking of agricultural development policies explains the variation in priorities for intervention in the sector from one policy to another, not only in terms of the value chains to be promoted, but also in terms of the agricultural development models desired.

The development of agricultural policies in Benin has also been subject to the vision of sector development carried by the governments in place (Adjovi, 2014) and to the evolution of regional and international agricultural policies. Since 1990, all the successive political regimes have had an agricultural sector policy document, under the influence of international partners. The development of agricultural policies thus seems to disregard the evolution of local socio-economic and environmental realities, thus reflecting the mimicry of public policies in Africa in the transfer of agricultural development models (Balié \& Fouilleux, 
2008). The implementation of these policies also depends financially and institutionally on development partners and are part of a sub-regional and international dynamic whose programs sometimes only partially overlap with the priorities defined by the State and local socio-economic realities and are generally of limited duration. The consequence is a succession of policies that do not agree, preventing the establishment of a sustainable national development model for the agricultural sector. The interventions of many African countries in the agricultural sector have thus long been more like a stack of actions carried out by many actors, most often foreign, rather than the reasoned implementation of a clearly stated agricultural policy (Ribier \& Baris, 2014). This lack of consensus in the elaboration of agricultural development policies is at the root of the poor performance observed in the agricultural sector.

Finally, Benin agricultural sector lacks long-term planning that would allow for a consensus on the future development of the sector. The planning tools are hardly more than 10 years old before they are replaced by another one. The instability of the policies will therefore lead in part to the unsustainability of these policies and explain why the sector's development strategies, although numerous, have rarely been set within a long-term perspective (Goura Soulé, 2012). For Krajeski (2014), the agricultural orientation law is the instrument used by the public authorities to plan the development of a certain type of farm. The absence of this law in the context of Benin's agricultural policies could justify this lack of coherence and continuity dynamics to provide sustainable solutions to the development of the agricultural sector. Overall, the gains resulting from the implementation of the agricultural sector development policy have not been sufficiently sustained over time to induce sustainable economic growth, sustained food security, a reduction in inequalities between men and women and, finally, rational management of natural resources.

\subsection{Dead End or Agricultural Sustainability}

The analysis of sustainability in agricultural policies of Benin highlights a shift in strategic orientations from the objectives of improving productivity to improving the attractiveness of the sector. The strategic objectives of agricultural policies declined according to the dimensions of sustainability show an imbalance and a weak integration of the conditions that guarantee the development of sustainable agriculture.

In the aftermath of the 1990s, the young democratic nation engaged in economic liberalism with the need for the agricultural sector to contribute to the strengthening of an economy weakened by the numerous structural adjustment plans. For a sector characterized by the predominance of poor subsistence family farms, it was necessary to develop market connection to create sources of income for farming families within the framework of the national poverty reduction strategy. This spirit animated interventions in the agricultural sector until the early 2000s when the adoption of the Millennium Development Goals (MDGs) took over from the new development priorities. With the first objective "Eradicate extreme poverty and hunger", the option of agricultural policies consisted of modernizing family farms to intensify production to meet this need. The policies developed during this period were part of this dynamic, to improve the viability of farms. This policy choice was 
confirmed with the food crisis of 2008, following which most sub-Saharan African states subsidized mineral fertilizers (Dugué et al., 2014) to enable farms to achieve productivity gains. In Benin, a real green revolution is being launched to modernize family farms and support entrepreneurial agriculture in response to this food crisis. The promotion of public-private partnership and the development of market instruments are all manifestations of this orientation (Ribier \& Baris, 2014). Agricultural working conditions are also being improved through easier access to work materials and subsidized inputs, to make the sector more attractive by reducing the drudgery of different farming operations.

These policy choices are in favor of the development of productivist agriculture, which is often contrasted with ecological agriculture when addressing the issue of agricultural sustainability. Yet, conventional and organic agriculture does not seem to be able to meet the food, ecological and human challenge, launched by a world population growth peaking at 9 billion people around 2050 (Chambon, 2009). The proposed solution lies in a doubly green revolution (Chambon, 2009; Griffon, 1996) that should allow the economic, social and ecological dimensions of sustainability to be taken into account in an integrated manner.

\section{Conclusion}

Public intervention in Benin's agricultural sector has always had as its objective the sustainable development of the sector. However, the processes that led to their adoption, as well as their content, have not always carried sustainability genes. The structure of policy documents is not based on the pillars of agricultural sustainability and does not take into account local socio-economic and environmental constraints. As part of a trajectory of the evolution of farms towards a universal model followed by developed economies, agriculture in Benin is today in a transition where it has not integrated the principles to improve its productivity significantly way and is invited to turn back to traditional knowledge that was considered to be inefficient. In any case, the different orientations given to the agricultural sector have transformed existing farming systems. Research perspectives should highlight these transformations as well as the social representations of the sustainability of farms, in a context where the scientific community is questioning the future of farming systems and sustainable development models for agriculture.

\section{References}

Adjovi, I. S. M. (2014). The balance of institutional reforms in the agricultural sector of Benin: succession, repetition or lack of evaluation?

Amonmide, I., Dagbenonbakin, G., Agbangba, C. E., \& Akponikpe, P. (2019). Contribution to the evaluation of soil fertility in cotton cropping systems in Benin. 13(June), 1846-1860.

Amoussou, E., Vodounon, S. H. T., Hougni, A., Vissin, E. W., Houndenou, C., Mahe, G., \& Boko, M. (2016). Environmental change and ecosystems vulnerability on Benin Catchment of the River Niger., 10(October), 2183-2201. https://doi.org/10.4314/ijbcs.v10i5.20

Assogba, S. C., Akpinfa, É., Gouwakinnou, G., \& Steim, L. (2017). The Sustainable Land Use: Analysis of experiences of agricultural development projects in Benin. 
Balié, J., \& Fouilleux, È. (2008). Stakes and Challenges of Common Agricultural Policies in Africa: A View from the Perspective. CAIRN.INFO, 2(46), 157-171. https://doi.org/10.3917/autr.046.0157

Banque Mondiale. (2020). Agricultural land (\% of territory). Agricultural Land (\% of Territory). https://donnees.banquemondiale.org/indicator/AG.LND.AGRI.ZS\%0ABarbier, J. M., \& Lopez-Ridaura, S. (2010). Assessment of the sustainability of agricultural production systems: limits of normative approaches and ways of improvement. ISDA, 1-9. https://doi.org/hal-00510528

Briquel, V., Vilain, L., Bourdais, J. L., Girardin, P., Mouchet, C., \& Viaux, P. (2001). The IDEA method (farm sustainability indicators): an educational approach. Ingénieries, EAT, IRSTEA, 29-39.

Chaboussou, A., \& Ruello, M. (2006). Study of a consultation process for the elaboration of a public policy: the case of the Senegalese Agro-Sylvo-Pastoral Orientation Law (LOASP). CIRAD-ES Working Paper.

http://www.museum.agropolis.fr/pages/savoirs/organisations_paysannes/chaboussou_ruello.p df

Chambon, N. (2009). To a doubly green revolution. Agriculture-environment: ambivalence and fragility at the heart of human equilibrium. Our Europe, 11.

Courade, G., \& Devèze, J. C. (2006). African agricultures facing difficult transitions.

Dugué, P., Autfray, P., Djamen, P., Girard, P., Olina, J., Ouedraogo, S., \& Vall, E. (2014). Agroecology for family farming in the South: deadlock or way forward? The case of savannah zones of cotton in West and Central Africa. Cirad, 22.

Felix, A. (2006). Elements for an overhaul of agricultural policies. CAIRN. INFO, 1(217), 159-172. https://doi.org/10.3917/afco.217.0159

Gafsi, M., Dugué, P., Jamin, J. Y., \& Brossier, J. (2007). Family Farms in West and Central Africa (QUAE).

Goura Soulé, B. (2012). ECOWAS Agricultural Policy: The Monograph of Benin, 24. http://www.slire.net/download/1530/polacedeao.pdf

Griffon, M. (1996). From the Green Revolution to the twice green revolution.

INSAE. (2015). RGPH4 : What to retain for population size in 2013 ?

Krajeski, D. (2014). The objectives of the future law for agriculture, food and forestry. 1-12.

Lairez, J., Feschet, P., Aubin, J., Bockstaller, C., \& Bouvarel, I. (2015). Agriculture and sustainable development. Guide for multi-criteria evaluation (Éditions Q).

Landais, E. (1998). Sustainable agriculture: the foundations of a new social contract? Courrier de l'environnement INRA, April, 1998(33), 18.

MAEP. (2017). Strategic Plan for the Development of the Agricultural Sector (PSDSA) 2025 
and the National Plan for Agricultural Investments and Food and Nutritional Security (PNIASAN)2017-2021. 132.

Mercoiret, M.-R. (2006). Farmers' organizations and agricultural policies.

Ribier, V., \& Baris, P. (2014). Vers un renouveau de politiques agricoles en Afrique? Cirad, 143-158.

Sirdey, N., Sester, M., \& Scopel, E. (2012). Design of a multi-criteria assessment tool for the sustainability of cropping systems. Adaptation and use in the context of Lake Alaotra.Terrier, M., Gasselin, P., \& Le Blanc, J. (2013). Assessing the Sustainability of Activity Systems to Support Households' Farming Projects (M.-C. A. A. \& S. da S. E. (Ed.) (ed.)).

Terrier, Médulline, Gasselin, P., \& Le Blanc, J. (2010). Assessing the sustainability of the activities systems of agricultural households to guide the projects of installation in agriculture. The EDAMA method. 14p. https://doi.org/hal-00523450

Tribier, V. (2014). Agriculture in quest of policy. Grain de Sel 41-42.

Zahm, F., Alonso, U. A., Boureau, H., Del'homme, B., Barbier, J. M., Gasselin, P., ... Redlingshofer B. (2015). Agriculture and Sustainable Farming: State of the Art and Proposal for Revisited Definitions in the light of the values, properties and boundaries of sustainability in agriculture. Innovations Agronomiques, 46(46), 105-125.

https://doi.org/http://doi.org/10.15454/1.462267509242779E12

Zahm, F., Ugaglia, A. A., Barbier, J., \& Boureau, H. (2019). Assessing the sustainability of farms. The IDEA $v 4$ method, a conceptual framework combining dimensions and properties of sustainability. April. https://doi.org/10.1051/cagri/2019004

\section{Copyright Disclaimer}

Copyright for this article is retained by the author(s), with first publication rights granted to the journal.

This is an open-access article distributed under the terms and conditions of the Creative Commons Attribution license (http://creativecommons.org/licenses/by/4.0/). 